\title{
Lactobacillus bobalius sp. nov., a lactic acid bacterium isolated from Spanish Bobal grape must
}

Correspondence Isabel Pardo Isabel.Pardo@uv.es
Eighteen different species of the genus Lactobacillus have been reported to be involved in the winemaking process (Chalfan et al., 1977; Costello et al., 1983; Davis et al., 1986; Lafon-Lafourcade, 1983; Lafon-Lafourcade et al., 1983; Maret \& Sozzi, 1977, 1979; Ribéreau-Gayon et al., 2000b; Rodas et al., 2005; Wibowo et al., 1985). In recent years, three of them have been described as novel species, namely Lactobacillus kunkeei (Edwards et al., 1998), Lactobacillus nagelii (Edwards et al., 2000) and Lactobacillus vini (Rodas et al., 2006). Wine lactobacilli are sometimes considered as spoilage organisms since they can produce acetic acid and/ or off-flavours (Davis et al., 1985; Wibowo et al., 1985; Fleet, 1993; Sponholz, 1993) and biogenic amines (Lonvaud Funel, 2001; Ribéreau-Gayon et al., 2000a; Landete et al., 2005).

Abbreviations: ARDRA, amplified rDNA restriction analysis; ISR, intergenic spacer region; RAPD, random amplification of polymorphic DNA.

The GenBank/EMBL/DDBJ accession number for the 16S rRNA gene sequence of strain $203^{\top}$ is AY681134.

Neighbour-joining and maximum-parsimony phylogenetic trees for strain $203^{\top}$ and members of the genus Lactobacillus are available as supplementary material with the online version of this paper.
In an earlier study, Rodas et al. (2005) carried out an extensive polyphasic analysis using genotypic and phenotypic methods to characterize 170 lactobacilli isolated from musts and wines. The dendrogram built by comparing the results obtained from the different techniques showed that strain $203^{\mathrm{T}}$ did not cluster with any of the reference species of the genus Lactobacillus. An analysis of $16 \mathrm{~S}$ rRNA gene sequence similarity showed that strain $203^{\mathrm{T}}$ was most closely related to the type strains of Lactobacillus kimchii (99.3\%), Lactobacillus paralimentarius $(97.8 \%)$ and Lactobacillus alimentarius (98.2\%). However, the study results did not confirm whether strain $203^{\mathrm{T}}$ represented a novel species or not.

The phylogenetic, genotypic and phenotypic characterization of isolate $203^{\mathrm{T}}$ and its closest phylogenetic relatives are studied in depth in our work, these issues having not been analysed by Rodas et al. (2005). On the basis of our results, it is proposed that strain $203^{\mathrm{T}}$ represents a novel species of the genus Lactobacillus.

Strain $203^{\mathrm{T}}$ was isolated from a Bobal wine from the Spanish Utiel-Requena Denominación de Origen (D.O.) by Rodas et al. (2005). In the current work, the following reference strains were used: L. alimentarius CECT $570^{\mathrm{T}}, L$. 
kimchii DSM $13961^{\mathrm{T}}$, Lactobacillus mali CECT 4149 (the type strain of Lactobacillus yamanishiensis), L. nagelii CECT $5983^{\mathrm{T}}$, L. paralimentarius DSM $13238^{\mathrm{T}}$, Lactobacillus satsumensis DSM $16230^{\mathrm{T}}$ and L. vini CECT $5924^{\mathrm{T}}$. All of them, as well as wine isolate $203^{\mathrm{T}}$, were grown in MRS broth (Scharlab) supplemented with $0.5 \mathrm{~g}$ L-cysteine hydrochloride $\mathrm{l}^{-1}$ (mMRS) under the conditions described by Rodas et al. (2003).

An almost-complete 16S rRNA gene sequence of isolate $203^{\mathrm{T}}$ was compared with those of its closest relatives. In the comparison, three species not previously described by Rodas et al. (2005) were included, namely Lactobacillus tucceti, Lactobacillus nantensis and Lactobacillus crustorum (Chenoll et al., 2006; Valcheva et al., 2006; Scheirlinck et al., 2007). Phylogenetic trees were constructed using neighbour-joining, maximum-parsimony and maximumlikelihood methods in the BioNumerics software package version 2.5 to infer the phylogeny of strain $203^{\mathrm{T}}$. The tree shown in Fig. 1 was constructed using the maximumlikelihood method. When other treeing methods were applied, the topology of the branches was the same (see Supplementary Fig. S1, available in IJSEM Online). The $16 \mathrm{~S}$ rRNA gene of strain $203^{\mathrm{T}}$ showed the following sequence similarities with respect to members of the genus Lactobacillus: $99.4 \%$ for L. kimchii MT-1077 ${ }^{\mathrm{T}}, 99.3 \%$ for $L$. paralimentarius DSM $13238^{\mathrm{T}}, 98.2 \%$ for L. alimentarius DSM $20249^{\mathrm{T}}, 97.8 \%$ for L. mindensis TMW $1.80^{\mathrm{T}}$ and $L$. crustorum LMG $23699^{\mathrm{T}}$, $97.7 \%$ for $L$. farciminis ATCC $29644^{\mathrm{T}}, 96.8 \%$ for $L$. nantensis $\mathrm{LP} 33^{\mathrm{T}}, 94.6 \%$ for $L$. versmoldensis $\mathrm{KU}-3^{\mathrm{T}}$ and $94 \%$ for L. tucceti CECT $5920^{\mathrm{T}}$. These similarity values are similar to those obtained by Rodas et al. (2005) in the case of L. kimchii and $L$. alimentarius; however, the value obtained with $L$. paralimentarius DSM $13238^{\mathrm{T}}$ was slightly different, because the sequence used by Rodas et al. (2005) (GenBank accession no. AB018528) was not the same as the one used in our study (AJ417500). We prefer to use the sequence AJ417500 to build trees as it is longer and seems more accurate than the one used previously. Following the phylogenetic analysis, we observed that strain $203^{\mathrm{T}}$ fell within the phylogenetic group L. alimentarius-L. farciminis, recently described by Felis \& Dellaglio (2007). The aforementioned work demonstrated how the phylogenetic structure of the genus Lactobacillus can change when novel species are introduced in the comparison, as is the case with $L$. tucceti and L. nantensis.

Although the 16S rRNA gene sequence similarities between strain $203^{\mathrm{T}}$ and the type strains of L. kimchii, $L$. paralimentarius, L. alimentarius, L. mindensis, L. crustorum and $L$. farciminis were greater than $97 \%$ (the level generally considered as the threshold for defining bacterial species; Stackebrandt \& Goebel, 1994), there was some evidence indicating that strain $203^{\mathrm{T}}$ differed from these species. Moreover, several Lactobacillus strains exhibiting more than $99 \%$ similarity with regard to their $16 \mathrm{~S}$ rRNA gene sequences represent distinct species (Bringel et al., 2001).

DNA-DNA hybridization experiments were performed with strain $203^{\mathrm{T}}$ and L. paralimentarius DSM $13238^{\mathrm{T}}$, L. kimchii DSM $13961^{\mathrm{T}}$ and L. alimentarius CECT $570^{\mathrm{T}}$, as described by Ziemke et al. (1998). The results, expressed as mean percentages based on three independent hybridization experiments, were $64.2,62.5$ and $42.6 \%$, respectively. Reciprocal hybridization experiments using genomic DNA from strain L. kimchii DSM $13961^{\mathrm{T}}$ as the template rendered a value of $52 \%$ with strain $203^{\mathrm{T}}$. As these values were below $70 \%$, strain $203^{\mathrm{T}}$ can be classified as representing a novel species (Stackebrandt \& Goebel, 1994).

Amplified rDNA restriction analysis (16S-ARDRA), analysis of the 16S-23S rDNA intergenic spacer region (ISR), random amplification of polymorphic DNA (RAPD) profiling and ribotyping were applied to characterize these strains genotypically, as described previously (Rodas et al., 2003, 2005; Chenoll et al., 2006). Strain $203^{\mathrm{T}}$ could be differentiated from the reference strains by using RAPD and ribotyping profiles. RAPD enabled differentiation of the four species because it is a technique directed at total DNA and is therefore a more powerful means of obtaining evidence of differences among species or strains. Ribotyping rendered different profiles, revealing different targets for EcoRI in the 23S rRNA gene or flanking regions and enabling species discrimination. ISR-DdeI showed small differences between L. alimentarius and the other species compared, while ISREcoRI gave two profiles (one shared by L. kimchii and strain

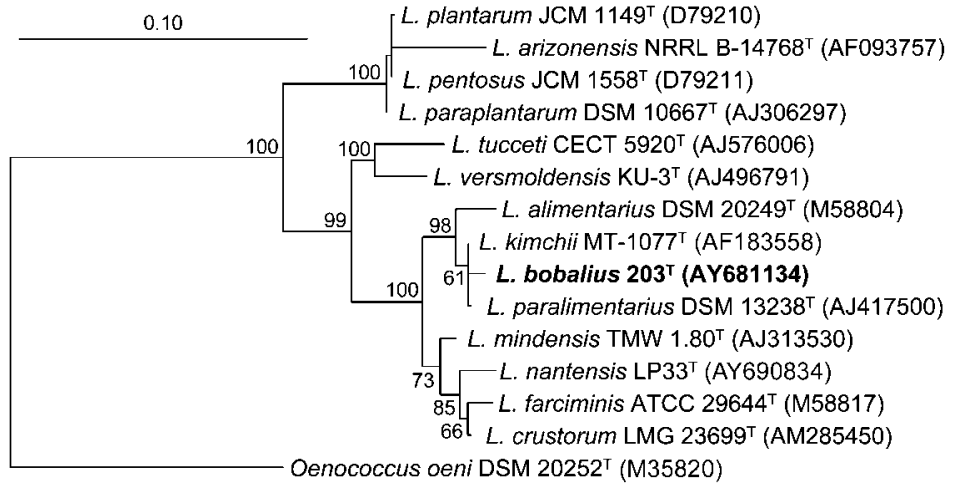

Fig. 1. Phylogenetic tree constructed using the maximum-likelihood method. Strain $203^{\top}$ joins with the type strains of $L$. alimentarius, L. kimchii and $L$. paralimentarius and is close to those of $L$. mindensis, $L$. nantensis, $L$. farciminis and $L$. crustorum. Bootstrap percentages (based on 1000 replications) are shown at nodes; only values $\geqslant 50 \%$ are shown. Oenococcus oeni DSM $20252^{\top}$ was used as an outgroup. Bar, $10 \%$ nucleotide substitution. Neighbour-joining and maximum-parsimony trees are available in Supplementary Fig. S1. 
$203^{\mathrm{T}}$ and the other shared by $L$. alimentarius and $L$. paralimentarius). As described recently by Ferchichi et al. (2008), analysis of the 16S-23S rRNA ISR is more suitable for differentiating between $L$. paralimentarius and related species that cannot be distinguished by analysing their 16S rRNA gene sequences. Ferchichi et al. (2008) reported slight differences in ISR sequences that allowed differentiation between $L$. alimentarius and $L$. paralimentarius, which we have demonstrated using ISR-DdeI profiles. However, they did not give data for L. kimchii. In the current study, restriction analysis of ISR sequences did not produce fingerprint differences that could be used to differentiate between L. kimchii and strain $203^{\mathrm{T}}$ (Fig. 2). 16S-ARDRA was not useful for distinguishing species, because of the high levels of similarity in their 16S rRNA gene sequences. As can be deduced from the composite dendrogram constructed using all of the fingerprinting analyses, four clusters showing $>58 \%$ similarity could be delineated, each of which comprised a single species (Fig. 2).

The $\mathrm{G}+\mathrm{C}$ content was determined by hydrolysing DNA enzymically and quantifying the nucleosides by using HPLC as reported previously (Tamaoka \& Komagata, 1984; Ziemke et al., 1998). Strain $203^{\mathrm{T}}$ has a DNA G $+\mathrm{C}$ content of $34.03 \pm 0.77 \mathrm{~mol} \%$, a value that is within the range (32$53 \mathrm{~mol} \%$ ) established for the genus Lactobacillus.

The peptidoglycan types for strain $203^{\mathrm{T}}$ and L. paralimentarius DSM $13238^{\mathrm{T}}$ were determined as described by Schleifer (1985) and Schleifer \& Kandler (1972), with the modification that TLC on cellulose was used instead of paper chromatography. Quantitative analysis of the peptidoglycan amino acids was performed using GC as described by MacKenzie (1987). From these results, it was concluded that strain $203^{\mathrm{T}}$ and L. paralimentarius DSM $13238^{\mathrm{T}}$ both possess peptidoglycan of the A4 $\alpha$ L-Lys-D-Asp type, just like their phylogenetic neighbours L. kimchii, $L$. alimentarius, L. mindensis and L. farciminis (Ehrmann et al., 2003). Dinitrophenylation (Schleifer, 1985) revealed that both strains contained aspartic acid as the N-terminal amino acid of the interpeptide bridge.

Strain $203^{\mathrm{T}}$ is a Gram-positive, catalase-negative, microaerophilic lactobacillus. It forms DL-lactate from glucose, no gas is released and it ferments gluconate and ribose and thus can be considered as facultatively heterofermentative.

Colonies are 1.8-2.0 $\mathrm{mm}$ in diameter, white, smooth and circular to slightly irregular when grown on mMRS agar at $28{ }^{\circ} \mathrm{C}$ for 4 days. Cells are rod-shaped, $0.71-1.03 \mu \mathrm{m}$ wide and $1.65-3.41 \mu \mathrm{m}$ long (mean, $0.92 \times 2.42 \mu \mathrm{m}$ ). Cells are non-motile, non-spore-forming and generally occur in pairs (but can also form short chains comprising up to five cells).

Strain $203^{\mathrm{T}}$ grows at $15,25,37$ and $45^{\circ} \mathrm{C}$ but not at $5{ }^{\circ} \mathrm{C}$. It grows at $\mathrm{pH} 3.3,4.5$ and 8.0 and in the presence of $5 \%$ (but not $10 \%)(\mathrm{w} / \mathrm{v}) \mathrm{NaCl}$. It produces neither exopolysaccharides from sucrose nor ammonia from arginine.

The ability of strain $203^{\mathrm{T}}$ and reference species to ferment carbohydrates was tested with API $50 \mathrm{CHL}$ galleries

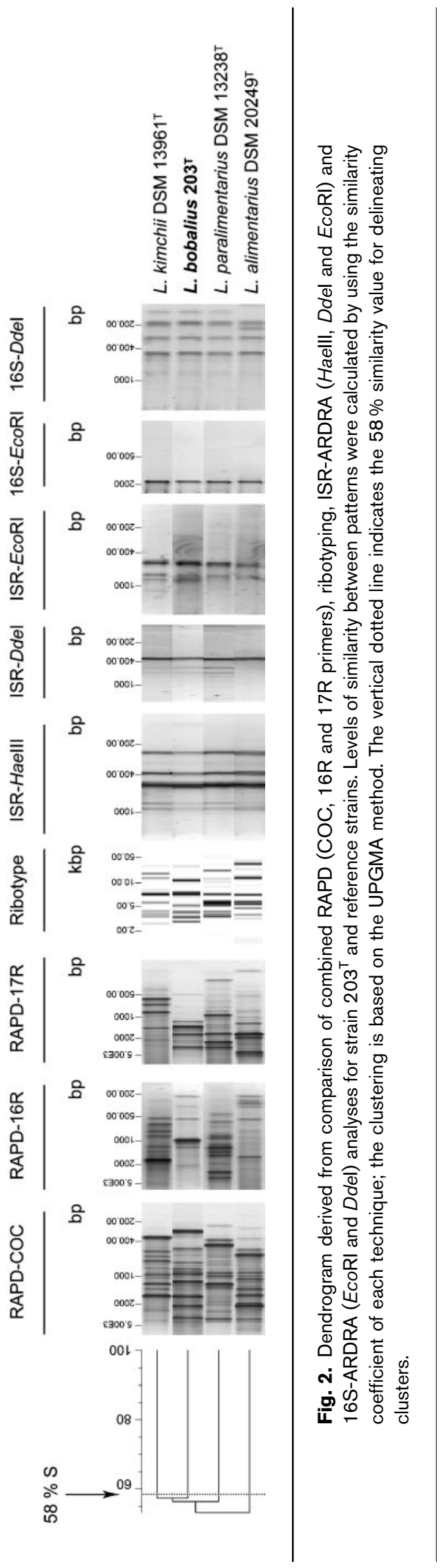


Table 1. Differential traits for strain $203^{\top}$ with respect to its closest phylogenetic neighbours, L. alimentarius, L. kimchii and $L$. paralimentarius

Strains: 1, strain $203^{\mathrm{T}}$; 2, L. alimentarius CECT $570^{\mathrm{T}}$; 3, L. kimchii DSM $13961^{\mathrm{T}}$; 4, L. paralimentarius DSM $13238^{\mathrm{T}}$. Data were obtained in this study unless otherwise indicated. All of the strains are positive for the following: growth with $5 \% \mathrm{NaCl}$ and fermentation of $\mathrm{D}$ ribose, D-glucose, D-fructose, D-mannose, $\mathrm{N}$-acetylglucosamine, amygdalin, arbutin, aesculin ferric citrate, salicin, cellobiose, maltose, sucrose, trehalose and gentiobiose. All are negative for the following: production of $\mathrm{CO}_{2}$ from glucose, ammonia from arginine, mannitol from fructose and dextran from sucrose and fermentation of glycerol, erythritol, D-arabinose, L-xylose, D-adonitol, methyl $\beta$-xyloside, Lsorbose, rhamnose, dulcitol, inositol, mannitol, sorbitol, methyl $\alpha$-Dmannoside, methyl $\alpha$-D-glucoside, lactose, melibiose, inulin, raffinose, starch, glycogen, xylitol, turanose, D-lyxose, D-tagatose, D- and Lfucose, D- and L-arabitol and 5-ketogluconate. +, Positive; -, negative; $\mathrm{w}$, weakly positive; ND, no data available.

\begin{tabular}{|lcccc|}
\hline Characteristic & $\mathbf{1}$ & $\mathbf{2}$ & $\mathbf{3}$ & $\mathbf{4}$ \\
\hline Growth in MRS with $10 \%$ & - & $+^{a *}$ & $-{ }^{b}$ & $-^{c}$ \\
$\mathrm{NaCl}$ & & & & \\
Growth in MRS at pH 3.3 & + & - & $-^{b}$ & $-^{c}$ \\
Fermentation of: & & & & \\
L-Arabinose & - & + & + & - \\
D-Xylose & - & - & + & - \\
Galactose & - & + & $\mathrm{W}$ & - \\
Melezitose & + & - & + & - \\
Gluconate & + & + & + & - \\
2-Ketogluconate & - & $\mathrm{W}$ & - & - \\
Gas production from & $\mathrm{W}$ & - & + & $-{ }^{a}$ \\
$\quad$ gluconate & & & & \\
Lactic acid isomer & $\mathrm{DL}$ & $\mathrm{L}(\mathrm{D})^{a}$ & $\mathrm{DL}^{b}$ & $\mathrm{ND}$ \\
DNA G+C content & $33.26-34.80$ & $36-37^{a}$ & $35^{b}$ & $37.2-38^{c}$ \\
(mol\%) & & & & \\
\hline
\end{tabular}

${ }^{\star}$ Data from other studies as follows: $a$, Reuter (1983); $b$, Yoon et al. (2000); c, Cai et al. (1999).

(bioMérieux) according to the manufacturer's instructions. Strain $203^{\mathrm{T}}$ ferments ribose, glucose, fructose, mannose, $\mathrm{N}$-acetylglucosamine, amygdalin, arbutin, salicin, cellobiose, maltose, sucrose, trehalose, melezitose, $\beta$-gentiobiose and gluconate and hydrolyses aesculin. It does not ferment glycerol, erythritol, D-arabinose, L-arabinose, D-xylose, L-xylose, adonitol, methyl $\beta$-xyloside, galactose, L-sorbose, rhamnose, dulcitol, inositol, mannitol, sorbitol, methyl $\alpha$-D-mannoside, methyl $\alpha$-D-glucoside, lactose, melibiose, inulin, raffinose, starch, glycogen, xylitol, turanose, Dlyxose, D-tagatose, D-fucose, L-fucose, D-arabitol, L-arabitol, 2-ketogluconate or 5-ketogluconate (Table 1). Strain $203^{\mathrm{T}}$ differs from L. paralimentarius in its ability to grow at pH 3.3 and to ferment melezitose and gluconate (Cai et al., 1999). Unlike L. alimentarius, strain $203^{\mathrm{T}}$ is unable to grow with $10 \% \mathrm{NaCl}$, is able to grow at $\mathrm{pH} 3.3$ and can ferment melezitose but not L-arabinose (Reuter, 1983). Strain $203^{\mathrm{T}}$ differs from L. kimchii in its ability to grow at $\mathrm{pH} 3.3$ and in its inability to ferment L-arabinose and D-xylose (Yoon et al., 2000) (see Table 1).

All of these data serve to confirm the separate status of strain $203^{\mathrm{T}}$ at the species level.

\section{Description of Lactobacillus bobalius sp. nov.}

Lactobacillus bobalius (bo.ba'li.us. N.L. masc. adj. bobalius pertaining to the grape variety Bobal).

Cells are Gram-positive, non-motile, non-spore-forming rods, 0.71-1.03 $\mu \mathrm{m}$ wide and 1.65-3.41 $\mu \mathrm{m}$ long. Cells are found singly, in pairs and in short chains. Microaerophilic. Colonies on MRS agar after 4 days incubation at $28{ }^{\circ} \mathrm{C}$ are $1.8-2.0 \mathrm{~mm}$ in diameter, smooth, circular to slightly irregular and white. Catalase-negative. Grows at 15$45{ }^{\circ} \mathrm{C}$, but not at $5{ }^{\circ} \mathrm{C}$. Facultatively heterofermentative; no gas is produced from glucose. DL-Lactate is produced as an end product from hexoses and pentoses. Ammonia is not produced from arginine and mannitol is not produced from fructose. Dextran is not produced from sucrose. Citric and malic acids are used. Ferments ribose, glucose, fructose, mannose, $\mathrm{N}$-acetylglucosamine, amygdalin, arbutin, salicin, cellobiose, maltose, sucrose, trehalose, melezitose, $\beta$-gentiobiose and gluconate and hydrolyses aesculin. Does not ferment glycerol, erythritol, D- or L-arabinose, Dor L-xylose, adonitol, methyl $\beta$-xyloside, galactose, Lsorbose, rhamnose, dulcitol, inositol, mannitol, sorbitol, methyl $\alpha$-D-mannoside, methyl $\alpha$-D-glucoside, lactose, melibiose, inulin, raffinose, starch, glycogen, xylitol, turanose, D-lyxose, D-tagatose, D- or L-fucose, D- or Larabitol or 2- or 5-ketogluconate. The DNA G + C content of the type strain is $34.03 \pm 0.77 \mathrm{~mol} \%$. The cell wall contains peptidoglycan of the A $4 \alpha$ L-Lys-D-Asp type.

The type strain, $203^{\mathrm{T}}$ (=CECT $7310^{\mathrm{T}}=\mathrm{DSM} 19674^{\mathrm{T}}$ ), was isolated in 1997 by one of the authors (A.M. R.) from a Bobal grape must.

\section{Acknowledgements}

This work was partly supported by CYCYT ALI97-1077-C02-01, AGL2000-0827-C02-01 and AGL2003-03689. We wish to thank Dr Ramón Rosselló-Mora for kindly helping with the hybridization analysis and for discussing the results. We also thank Professor Dr H. G. Trüper for giving us advice about the species name.

\section{References}

Bringel, F., Quénée, P. \& Tailliez, P. (2001). Polyphasic investigation of the diversity within Lactobacillus plantarum related strains revealed two L. plantarum groups. Syst Appl Microbiol 24, 561-571.

Cai, Y., Okada, H., Mori, H., Benno, Y. \& Nakase, T. (1999). Lactobacillus paralimentarius sp. nov., isolated from sourdough. Int J Syst Bacteriol 49, 1451-1455.

Chalfan, Y., Goldberg, I. \& Mateles, R. J. (1977). Isolation and characterization of malo-lactic bacteria from Israeli red wines. J Food Sci 42, 939-943. 
Chenoll, E., Macián, M. C. \& Aznar, R. (2006). Lactobacillus tucceti sp. nov., a new lactic acid bacterium isolated from sausage. Syst Appl Microbiol 29, 389-395.

Costello, P. J., Morrison, G. J., Lee, T. H. \& Fleet, G. H. (1983). Numbers and species of lactic acid bacteria in wines during vinification. Food Technol Aust 35, 14-18.

Davis, C. R., Wibowo, D., Eschenbruch, R., Lee, T. H. \& Fleet, G. H. (1985). Practical implications of malolactic fermentation: a review. Am J Enol Vitic 36, 290-301.

Davis, C. R., Wibowo, D., Lee, T. H. \& Fleet, G. H. (1986). Growth and metabolism of lactic acid bacteria during and after malolactic fermentation of wines at different pH. Appl Environ Microbiol 51, 539-545.

Edwards, C. G., Haag, K. M., Collins, M. D., Hutson, R. A. \& Huang, Y. C. (1998). Lactobacillus kunkeei sp. nov.: a spoilage organism associated with grape juice fermentations. J Appl Microbiol 84, 698-702.

Edwards, C. G., Collins, M. D., Lawson, P. A. \& Rodriguez, A. V. (2000). Lactobacillus nagelii sp. nov., an organism isolated from a partially fermented wine. Int J Syst Evol Microbiol 50, 699-702.

Ehrmann, M. A., Muller, M. R. A. \& Vogel, R. F. (2003). Molecular analysis of sourdough reveals Lactobacillus mindensis sp. nov. Int $J$ Syst Evol Microbiol 53, 7-13.

Felis, G. E. \& Dellaglio, F. (2007). Taxonomy of lactobacilli and bifidobacteria. Curr Issues Intest Microbiol 8, 44-61.

Ferchichi, M., Valcheva, R., Prevost, H., Onno, B. \& Dousset, X. (2008). A one-step reaction for the rapid identification of Lactobacillus mindensis, Lactobacillus panis, Lactobacillus paralimentarius, Lactobacillus pontis and Lactobacillus frumenti using oligonucleotide primers designed from the 16S-23S rRNA intergenic sequences. J Appl Microbiol 104, 1797-1807.

Fleet, G. H. (1993). The microorganisms of winemaking. Isolation, enumeration and identification. In Wine Microbiology and Biotechnology, pp. 1-25. Edited by G. H. Fleet. Chur: Harwood Academic.

Lafon-Lafourcade, S. (1983). Wine and brandy. In Biotechnology, vol. 5, pp. 81-163. Edited by G. Reed. Basel: Verlag Chemie.

Lafon-Lafourcade, S., Carre, E. \& Ribéreau-Gayon, P. (1983). Occurrence of lactic acid bacteria during different stages of vinification and conservation of wines. Appl Environ Microbiol 46, 874-880.

Landete, J. M., Ferrer, S. \& Pardo, I. (2005). Which lactic acid bacteria are responsible of histamine production in wine? J Appl Microbiol 99, 580-586.

Lonvaud-Funel, A. (2001). Biogenic amines in wine: role of lactic acid bacteria. FEMS Microbiol Lett 199, 9-13.

MacKenzie, S. L. (1987). Gas chromatographic analysis of amino acids as the $N$-heptafluorobutyryl isobutyl esters. J Assoc Off Anal Chem 70, 151-160.

Maret, R. \& Sozzi, T. (1977). Flore malolactique de moûts et de vins du Canton du Valais (Suisse). I. Lactobacilles et pédiocoques. Ann Technol Agric 27, 255-273 (in French).

Maret, R. \& Sozzi, T. (1979). Flore malolactique de moûts et de vins du Canton du Valais (Suisse). II. Évolution des populations de lactobacilles et de pédiocoques au cours de la vinification d'un vin blanc (un Fendant) et d'un vin rouge (un Dole). Ann Technol Agric 28, 31-40 (in French).

Reuter, G. (1983). Lactobacillus alimentarius sp. nov., nom. rev. and Lactobacillus farciminis sp. nov., nom. rev. Syst Appl Microbiol 4, 277-279.

Ribéreau-Gayon, P., Dubourdieu, D., Donèche, B. \& Lonvaud, A. (2000a). Metabolism of lactic acid bacteria. In Handbook of Enology, vol. 1, pp. 129-148. Edited by P. Ribéreau-Gayon. Chichester: Wiley.

Ribéreau-Gayon, P., Dubourdieu, D., Donèche, B. \& Lonvaud, A. (2000b). Lactic acid bacteria development in wine. In Handbook of Enology, vol. 1, pp. 149-167. Edited by P. Ribéreau-Gayon. Chichester: Wiley.

Rodas, A. M., Ferrer, S. \& Pardo, I. (2003). 16S-ARDRA, a tool for identification of lactic acid bacteria isolated from grape must and wine. Syst Appl Microbiol 26, 412-422.

Rodas, A. M., Ferrer, S. \& Pardo, I. (2005). Polyphasic study of wine Lactobacillus strains: taxonomic implications. Int J Syst Evol Microbiol 55, 197-207.

Rodas, A. M., Chenoll, E., Macián, M. C., Ferrer, S., Pardo, I. \& Aznar, R. (2006). Lactobacillus vini sp. nov., a wine lactic acid bacterium homofermentative for pentoses. Int J Syst Evol Microbiol 56, 513-517.

Scheirlinck, I., Van der Meulen, R., Van Schoor, A., Huis, G., Vandamme, P., De Vuyst, L. \& Vancanneyt, M. (2007). Lactobacillus crustorum sp. nov., isolated from two traditional Belgian wheat sourdoughs. Int J Syst Evol Microbiol 57, 1461-1467.

Schleifer, K. H. (1985). Analysis of the chemical composition and primary structure of murein. Methods Microbiol 18, 123-156.

Schleifer, K. H. \& Kandler, O. (1972). Peptidoglycan types of bacterial cell walls and their taxonomic implications. Bacteriol Rev 36, 407-477.

Sponholz, W. R. (1993). Wine spoilage by microorganisms. In Wine Microbiology and Biotechnology, pp. 395-420. Edited by G. H. Fleet. Chur: Harwood Academic.

Stackebrandt, E. \& Goebel, B. M. (1994). Taxonomic note: a place for DNA-DNA reassociation and $16 \mathrm{~S}$ rRNA sequence analysis in the present species definition in bacteriology. Int J Syst Bacteriol 44, 846-849.

Tamaoka, J. \& Komagata, K. (1984). Determination of DNA base composition by reversed-phase high-performance liquid chromatography. FEMS Microbiol Lett 25, 125-128.

Valcheva, R., Ferchichi, M. F., Korakli, M., Ivanova, I., Gänzle, M. G., Vogel, R. F., Prevost, H., Onno, B. \& Dousset, X. (2006). Lactobacillus nantensis sp. nov., isolated from French wheat sourdough. Int J Syst Evol Microbiol 56, 587-591.

Wibowo, D., Eschenbruch, R., Davis, C. R., Fleet, G. H. \& Lee, T. H. (1985). Occurrence and growth of lactic acid bacteria in wine: a review. Am J Enol Vitic 36, 302-313.

Yoon, J. H., Kang, S. S., Mheen, T. I., Ahn, J. S., Lee, H. J., Kim, T. K., Park, C. S., Kho, Y. H., Kang, K. H. \& Park, Y. H. (2000). Lactobacillus kimchii sp. nov., a new species from kimchi. Int J Syst Evol Microbiol 50, 1789-1795.

Ziemke, F., Höfle, M. G., Lalucat, J. \& Rosselló-Mora, R. (1998). Reclassification of Shewanella putrefaciens Owen's genomic group II as Shewanella baltica sp. nov. Int J Syst Bacteriol 48, 179-186. 